\title{
Hookworm infection and anemia in adult women in rural Chiapas, Mexico
}

Paula E. Brentlinger, MD, MPH, (1) Linnea C apps, MD, MPH, (2) Melinda Denson, RN , MPH. ${ }^{(3)}$

\section{Brentlinger PE, Capps L, Denson M. Hookworm infection and anemia in adult women in rural Chiapas, Mexico. Salud Publica Mex 2003;45:117-119. The English version of this paper is available too at: http://www.insp.mx/salud/index.html}

\begin{abstract}
A bstract
Objective. To describe associations between anemia and hookworm (Necator americanus) infection in hospitalized women in rural Chiapas, Mexico. Material and Methods. We retrospectively reviewed the hospital records of 68 anemic women (defined as having a hemoglobin level $<10 \mathrm{mg} / \mathrm{dl}$ ) or with intestinal parasitism, identified through hospital discharge and transfusion records for the calendar year 1999. The medical charts of 86 cases were located, 18 of which were not confirmed as anemia cases. The hospital is located in Altamirano, C hiapas. Characteristics of subjects were compared using Student's t-test (for continuous variables) and the $\chi^{2}$ test (for categorical variables). A $p$-value $\leq 0.01$ was used for statistical significance. Chart review and data analysis took place during the year 2000 . Results. Fifty percent of women who had stool examinations were infected with $\mathrm{N}$. americanus. Necator often coexisted with other potential causes of anemia, such as pregnancy and hemorrhage. H emoglobin levels in hookworm-infected women (mean $4.1 \mathrm{~g} / \mathrm{dl}$ ) were significantly lower than in uninfected women (mean $7.0 \mathrm{gm} /$ $\mathrm{dl}$ ), and Necator prevalence was significantly higher in the anemic women $(50 \%)$ than in the overall hospital population (1.9\%).Conclusions.A nemic women should be offered stool testing where Necator is present, and should be considered for antihelminthic treatment even if pregnant. Further inves-
\end{abstract}

\author{
Brentlinger PE, Capps L, Denson M. \\ Anemia e infección por Necator americanus \\ en mujeres en Chiapas, México. \\ Salud Publica Mex 2003;45:117-119. \\ El texto completo en inglés de este artículo también \\ está disponible en: http://www.insp.mx/salud/index.html
}

\section{Resumen}

Objetivo. Describir la asociación entre anemia severa e infección con Necator americanus en una población de mujeres ho spitalizadas en el estado de C hiapas, México. Material y métodos. En el registro de ingresos del año 1999 de un hospital rural en Altamirano, C hiapas, se identificaron a las pacientes con diagnósticos de egreso de anemia (definida como hemoglobina<10mg/dl) y/o parasitosis intestinal. También se revisó el registro de transfusiones para identificar a las mujeres mayores de 14 años de edad que recibieron sangre. La revisión de expedientes y el análisis de datos se llevó a cabo en el año 2000. Las comparaciones de las características de las pacientes se hicieron con la prueba t de Student (para variables continuas) y la prueba $\chi^{2}$ (para variables categóricas). La significancia estadística se estableció con un valor de $p \leq 0.01$. Resultados. En las mujeres en quienes se realizó examen coproscópico, $50 \%$ tuvieron $\mathrm{N}$. americanus. La presencia de $\mathrm{N}$. americanus no excluyó la presencia de otro factor de riesgo para anemia, por ejemplo embarazo o hemorragia. Los niveles de hemoglobina de las mujeres infectadas con $\mathrm{N}$. americanus fueron significativamente más bajos (promedio $4.1 \mathrm{~g} / \mathrm{dl}$ ) que los de las demás mujeres anémicas (promedio $7.0 \mathrm{gm} / \mathrm{dl}$ ), y la prevalencia de $\mathrm{N}$. americanus en mujeres anémicas fue más alta $(50.0 \%)$ que en la población atendida por el hospital (1.9\%).

Doctors for G lobal Health and Doctors of the W orld-USA supported this investigation financially.

(1) International Health Program, School of Public Health and Community Medicine, University of W ashington, Seattle, W ashington, USA, (also Program Department D octors of the World-USA N ew York, N ew York, USA).

(2) Department of Internal Medicine, Columbia University College of Physicians and Surgeons N ew York, N ew York, USA.

(3) Doctors of the World-USA, N ew York, N ew York, USA.

Received on: A pril 8,2002 • Accepted on: N ovember 5,2002

Address reprint requests to: D ra. Capps, Department of Medicine Harlem Hospital, 506 Lenox Avenue, Room 14101, N ew York, N ew York 10037

Email: Ic9@ columbia.edu 
tigation is recommended among wo men in Chiapas, and probably elsewhere in M exico.The English version of this paper is available too at: http://www.insp.mx/salud/index.html

Key words: anemia; Necator americanus; maternal and child health; M exico
Conclusiones. A unque la prevalencia de infección con $\mathrm{N}$. americanus no se considera alta en la población general mexicana, fue importante en las mujeres anémicas que se sometieron a coproscopía en nuestro estudio. Las mujeres anémicas ameritan coproscopía donde existe N . americanus, y pueden requerir tratamiento, aunque estén embarazadas. El tema de la asociación de anemia en la población femenina e infección con $\mathrm{N}$. americanus merece más investigación en C hiapas, y posiblemente en otros estados de México. El texto completo en inglés de este artículo también está disponible en: http://www.insp.mx/salud/index.html

Palabras clave: anemia; Necator americanus; salud materno infantil; México
S evere iron-deficiency anemia is thought to be associated with a greater than threefold elevation in the risk of maternal mortality, and is also highly associated with maternal and fetal morbidity. ${ }^{1,2}$ It is commonly multifactorial. Local prevalence of risk factors for iron deficiency and anemia may vary broadly between populations. For example, where falciparum malaria infection or the acquired immunodeficiency syndrome are common, they are important contributors to anemia in women of reproductive age. 3,4 Hookworm infection, whose prevalence also varies by geographic region, may also serve as an important cause of iron deficiency in women of reproductive age. ${ }^{5}$ Greater parasite burdens have been associated with poorer maternal iron status and reduced fetal growth. ${ }^{6}$ Although hookworm is believed to be uncommon in the general Mexican population, ${ }^{7}$ specific population subgroups may still be at high risk. Prompted by a cluster of cases of severe anemia associated with Necator americanus infection in adult women in a hospital serving the rural, indigenous poor in Chiapas, Mexico, we investigated the prevalence of hookworm in anemic women admitted to that facility. The study hospital is located in the Selva administrative region of Chiapas, and its patient population was predominantly derived from the Selva and Altos regions.

\section{Material and Methods}

This was a retrospective review of hospital records. The study protocol was approved by the medical staff and administration of the study hospital. We searched year 1999 logs of patient discharges and blood transfusions for patients who satisfied the following criteria: Female, age $>14$ years, and discharge diagnosis of anemia or intestinal parasites. We also searched the transfusion $\log$ for female patients $>14$ years of age regardless of diagnosis, and examined the hospital laboratory log for the month of June, 1999, the approximate midpoint of the study year. Characteristics of subjects were compared using Student's t-test (for continuous variables) and the $\chi^{2}$ test (for categorical variables). Chart review and data analysis took place during the year 2000 .

\section{Results}

One hundred patients satisfied our inclusion criteria. Fourteen medical records were unavailable for review, and 18 did not confirm the diagnosis of anemia (defined as hemoglobin $<10 \mathrm{~g} / \mathrm{dl}$ ). Of the remaining 68 patients, $36(53 \%)$ had one or more stool examinations performed for ova and parasites. Of these, 18 (50\%) revealed Necator americanus; a significantly $(\mathrm{p}<0.001)$ higher prevalence than the $1.9 \%$ (8 of 417) prevalence detected in the overall hospital patient population in the one-month sample. Other results of the review are presented in the table I.

The presence of another likely cause for anemia -such as post-partum bleeding or gastrointestinal hemorrhage- did not exclude infection with hookworm. However, presence of another likely cause of anemia was associated with a smaller likelihood that ova and parasite examination would be performed: $25 \%$ of anemic women with current or recent pregnancy underwent stool examination, compared to $63 \%$ of anemic women without such a history. 
Table I

\section{Characteristics of study subjects. Chiapas, Mexico, 1999}

Patient characteristics

(Hospitalized women $>14$ years of age, Hemoglobin $<10 \mathrm{~g} / \mathrm{dl}$ )
Results of stool exam for ova and parasites

Exam not performed Necator americanus present Necator americanus absent $(n=32)$ $(n=18)$

\begin{tabular}{|c|c|c|c|}
\hline Mean age in years (range) & $30.4(16-57)$ & 40.3 (17-68) & $42.7(16-75)$ \\
\hline Hemoglobin (mean, SD) & $7.1(+/-2.0)$ & $4.1(+/-1.9) *$ & $7.0(+/-2.0)$ \\
\hline Pregnant at time of admission (number, $\%$ ) & $8 \quad(25.0 \%)$ & $4 \quad(22.2 \%)$ & 0 \\
\hline Recent birth or spontaneous abortion (number, \%) & $(18.8 \%)$ & 0 & $(11.1 \%)$ \\
\hline Any source of current or recent blood loss (number, $\%$ ) & $19(59.4 \%)$ & $3 \quad(16.7 \%)$ & $(38.9 \%)$ \\
\hline Malignancy or hematologic disorder other than anemia (number, \%) & $5 \quad(15.6 \%)$ & 0 & $(11.1 \%)$ \\
\hline Malaria (number, \%) & $1 \quad(3.1 \%)$ & 0 & $(11.1 \%)$ \\
\hline Typhoid fever (number, \%) & 0 & 0 & $(5.6 \%)$ \\
\hline Transfused during admission (number, \%) & $22(68.8 \%)$ & $15 \quad(83.3 \%)$ & $(55.6 \%)$ \\
\hline HIV infection and/or AIDS & None tested & None tested & None tested \\
\hline
\end{tabular}

* Difference between mean hemoglobin levels of patients with and without confirmed $\mathrm{N}$ ecator infection was significant at $p<0.01$.

\section{Discussion}

Although we believe that the existence of 18 cases of hookworm-associated severe anemia in adult women admitted to a single rural medical facility during a single calendar year is noteworthy, the generalizability of our findings is limited by the study's small sample size and retrospective approach. Further investigation, with prospective identification of anemic women and systematic diagnosis of N. americanus and other potential contributors to iron deficiency, would be helpful.

Hookworm infestation can be associated with clinically important blood loss, consistent with our finding of significantly lower hemoglobins and a trend toward greater transfusion requirements in our hookworm-infected subjects. Some authorities have suggested that all women of childbearing age, including pregnant women in the $2^{\text {nd }}$ and $3^{\text {rd }}$ trimesters, could benefit from periodic antihelminthic treatment in areas endemic for hookworm, much as presumptive therapy for malaria infection is advised during late pregnancy in malarious regions. ${ }^{8,9}$ Mebendazole therapy has not been found to be hazardous to mother or infant after completion of the first trimester of pregnancy. ${ }^{10}$

Health professionals should consider hookworm as a possible cause of anemia in endemic areas regardless of the presence of pregnancy, bleeding, malignancy, or other infectious diseases associated with anemia (such as malaria, typhoid fever, and AIDS). Pregnancy is no longer considered an absolute contraindication to treatment when hookworm infestation is diagnosed, and deferral of treatment may be hazardous to both mother and infant.

\section{Acknowledgments}

Dr. Begoña Abad and Dr. Jorge Antón Lugo made helpful comments on study methodology and on final drafts.

\section{References}

1. G uidotti R. A naemia in pregnancy in developing countries. $\mathrm{Br}$ J $\mathrm{O}$ bstet Gynaecol 2000;107:437-438.

2. Brabin B, Hakimi M, Pelletier D. An analysis of anemia and pregnancyrelated maternal mortality. J N utr 2001;131:604S-615S.

3.Verhoeff F, Brabin B, Chimsuku I, Kazembe P, Broadhead R.An analysis of the determinants of anaemia in pregnant women in Malawi - a basis for action. Ann Trop Med Parasitol 199;93:119-133.

4. Bouvier P, D oumbo O, Breslow N, Robert C, Mauris A, Picquet $M$ et al. Seasonality, malaria, and impact of prophylaxis in a W est African village. I. Effect on anemia in pregnancy. Am J Trop Med Hyg 1997;56:378-383.

5. D reyfuss M, Stoltzfus R, Shrestha J, Pradhan E, LeC lerq S, Khatry $S$ et al. Hookworms, malaria and vitamin A deficiency contribute to anemia and iron deficiency among pregnant women in the plains of $\mathrm{N}$ epal. J N utr 2000;130:2527-2536.

6.W eigel MM, Calle A, Armijos RX, Vega IP, Bayas BV, Montenegro CE.The effect of chronic intestinal parasitic infections on maternal and perinatal outcome. Int J Gynaecol 0 bstet 1996: 52:9-17.

7.Tay J, RuizA, Sánchez-Vega JT, Romero-C abello R, Robert L, Becerril MA. Helmintiasis intestinal en la República de México. Bol Chil Parasitol 1995; 50:10-16.

8. Bundy D, de Silva N. C an we deworm this wormy world? Br Med Bull 1998:54:421-432.

9. Stoltzfus R, D reyfuss M, Chwaya H,Albonico M. Hookworm control as a strategy to prevent iron deficiency. $N$ utr Rev 1997;55:223-232.

10. De Silva N, Sirisena J, Gunasekera D, Ismail M, De Silva H. Effect of mebendazole therapy during pregnancy on birth outcome. Lancet 1999; 353:1145-1149. 